\title{
Landscapes shared by visibility: a case study on the settlement relationships of the Songgukri culture, Korea
}

\author{
Habeom Kim ${ }^{1} \cdot$ Christopher Bone ${ }^{2} \cdot$ Gyoung-Ah Lee ${ }^{1}$ (D) \\ Received: 23 June 2018 / Accepted: 23 October 2019 / Published online: 20 January 2020 \\ (C) The Author(s) 2020
}

\begin{abstract}
The Songgukri culture (c. 2900-2400 cal. BP) in the Geum River basin is often regarded as one of the earliest complex societies in the Korean peninsula, based on some evidence for an intensified agrarian economy and social differentiation. This study focuses on landscape visibility as a method of detecting settlement relationships of the Songgukri culture. Two measures of landscape visibility, viewshed size and shared-ness of viewshed ( $\mathrm{SoV}$ ), are examined in this study. Our results indicate that while Songgukri centers tend to have larger visibility of landscape than non-centers, both centers and non-centers share their visible landscape with other settlements at a remarkably high rate. We argue that landscape visibility at Songgukri settlements reflects a shared sense of cultural belonging among settlers, rather than sociopolitical inequality between the elites in centers and the nonelites in other settlements. This study highlights a long-term process, in which bottom-up cultural interactions of Songgukri residents may have contributed to the development of settlement organization and regional communal identities over time.
\end{abstract}

Keywords Visibility analysis · GIS $\cdot$ Landscape archeology $\cdot$ Settlement relationships $\cdot$ Bronze age Songgukri culture $\cdot$ Korea

\section{Introduction}

Visibility analysis is one of the most familiar geographic information system (GIS) methods in archeology. This computational technique allows users to investigate the visibility of physical objects or places at one point in a landscape. The method has been used initially in civil engineering, environmental management, and the military to select the location of a monitoring tower or TV/radio transmission tower as early as the 1960s (Amidon and Elsner 1968; Wang et al. 2000). Visibility analysis began to be applied to archeological cases in the 1990s with the increasing popularity of the GIS approach. Mirroring its original use, archeologists have used the method to investigate the visibility of settlements (e.g., Grau Mira 2003), monuments (e.g., Cummings and Whittle 2004; Wheatley 1995), and defensive sites in the past landscape (e.g., Smith and Cochrane 2011).

Gyoung-Ah Lee

galee@uoregon.edu

1 Department of Anthropology, University of Oregon, 1321 Kincaid Street, Eugene, OR 97403-1218, USA

2 Department. of Geography, Victoria university, PO Box 1700 STN CSC, Victoria, BC V8W 2Y2, Canada
However, archeological applications have been different in that they tend to focus on the experiential aspect of visibility (Verhagen 2018). That is, visibility is interpreted as a cognitive and perceptual phenomenon through which a human agent makes sense of the space (Llobera 2003). Thus, visibility analysis is used to study not merely the physical visibility of a place but also the cultural meaning behind being able (or unable) to see. Previous studies used visibility to examine abstract concepts that are more profound than physical visibility itself. These abstract concepts include settlement choice (Jones 2006), sociopolitical relationship among communities (Brughmans et al. 2015; Kosiba and Bauer 2013), phenomenological experience relating to a monument or landscape (Llobera 2001; Tschan et al. 2000), and mobility pattern (Murrieta-Flores 2014). While each study interprets the meaning of visibility differently, they all rely on a common premise - visibility relates. People tend to relate themselves to other people, places, and things that are visible.

We use the relational property of visibility to examine the settlement relationships of the Middle Bronze Age culture, also known as Songgukri (ca. 2900-2400 cal. BP). Its type site, the Songgukri site, was first uncovered in Buyeo city of South Chungcheong province in southwestern Korea in 1974 (Ahn and Kim 1975; National Museum of Korea 1979). Since then, Songgukri culture has occupied a special place in Korean archeology as its emergence appears to coincide with the development 
of social complexity and intensive rice agriculture. For over 40 years of research, individual accounts of artifacts and architectural structures have prevailed over the comprehensive understanding of the Songgukri settlements. A welcome trend in recent years is a growing body of literatures that expand their scope to regional landscapes (e.g., Lee 2004; Lee 2007), settlement organizations (e.g., Ahn 2004; Kim 2006c), social structures (e.g., Lee 2009), political economy (e.g., Bale 2017; Bale and Ko 2006; Grier and Kim 2012), and long-term cultural trajectories (e.g., Kim 2006b; Lee 2016).

The current discourse on Songgukri settlement relationships, however, disproportionately focuses on the theoretical framework of chiefdom and settlement hierarchy. Chiefdom society is seen as an evolutionary bridge that links tribe and state-level societies (Earle 1987; Flannery 1995). It is marked by the specialization in leadership roles over resource extraction and redistribution as a means of exerting the elites' political influence over local communities (Earle 1987, Service 1975). Since Songgukri culture preceded the earliest statelevel societies in Korea, the chiefdom model has been highly influential for the explanation of the Songgukri social organization (Kim 2014b; Rhee and Choi 1992). Under the chiefdom model, the discussions on settlement relationships are often centered on a settlement hierarchy, where the elites in major political centers control resources and labor from noncenters.

As an alternative to such rigid hierarchical models, we present an emic perspective on how Songgukri people related themselves to those in neighboring villages through visibility analysis. Our working hypothesis is based on the previous studies' premise that social groups strategize landscape visibility in order to gain increased access to and supervision over key resources and important spaces (Grau Mira 2003; Jones 2006; Lock and Harris 1996). We hypothesize that if the elites in Songgukri centers engaged in the extraction of resources and labors from the non-centers, then they would have maintained a watch over the visible area of the non-centers. The visible area of the non-centers would include their farming fields and raw material sources. Easy visual access to this area would have been advantageous for the elites. Thus, we expect that the centers' visible area would be larger than that of the non-centers. Also, the extent of the shared visible space between the centers and the non-centers would be high if our working hypothesis is correct. For the visibility pattern among the non-centers, the opposite is expected. The visible space of the non-centers would be smaller than the centers. Also, since the noncenters would not share their visible space with each other, the extent of their sharing of visible space would be low. We compare two measures of landscape visibility to test this hypothesis, one based on the viewshed size and the other on the shared-ness of viewshed between Songgukri centers and other non-centers.

\section{Materials and methods}

\section{Archeological background}

Songgukri culture is defined by its material assemblage distinctive from the previous and contemporaneous Mumun (Bronze Age) cultures. It shows the development of craft production of bronze and jade objects, changes in pottery tradition and architectural styles of pit houses and burials, and increasing investments in defensive structures (Bale and Ko 2006; Kim 2015a). This distinctive culture first appeared along the Geum River in southwestern Korea around 2900 cal. BP (Lee 2011a; Lee 1988), and then expanded to much of the south-central peninsula, Jeju Island (Kim 2010b), and finally to northern Kyushu, Japan (Lee 2006) within the next two centuries. The expansion and growth of the Songgukri culture are labeled as the Middle Bronze or Mumun period (2900-2400 cal. BP). Songgukri culture is often regarded as an emerging complex society fueled by class differentiation and craft specialization. While draft animal use is not confirmed during this period (Lee 2011b), Songgukri people practiced intensive rice agriculture as attested by abundant rice remains and irrigation canals found at Songgukri settlements (Archaeology Center of Korea National University of Cultural Heritage 2013; Archaeology Center of Korea University 2004). Other studies questioned the importance of rice as staples (Kim 2015b; Lee 2003). Instead, a wide range of resources was utilized in the Songgukri culture through multi-cropping and hunting of wild terrestrial mammals (Kwak et al. 2017).

Discussions of the Songgukri settlement relationships have been focused on resource extraction and redistribution. Kim (2008) and Grier and Kim (2012) suggested that Songgukri centers consumed agricultural surplus produced from noncenters. Their political economy model is based on the disparity of storage space between the centers and the non-centers: Songgukri centers relatively lacked storage features while non-centers have increased storage capacity. Similarly, Kim (2006c) analyzed the locational advantage of multiple Songgukri settlements. He used various proxy data such as modern agricultural zoning data for gauging land productivity and the historical road networks for measuring the transportability of resources. In his argument, top-tier Songgukri settlements were located where large-scale labors could be easily pooled and agricultural surplus could be efficiently transported. Both studies understood Songgukri settlement relationships through a lens of hierarchy where settlements were ranked by their managerial potential to mobilize labor and to control resources. The specific nature of the relationship between ranked settlements varies by scholars. For example, Kim (2008) and Grier and Kim (2012) emphasized the direct economic and political dependency of noncenters to centers. On the other hand, Kim (2006c) considered 
that the Songgukri settlement system was maintained by a mix of "top-down" and "bottom-up" political strategies; the former emphasizes the elites' managerial role and the latter the cooperation among local household groups.

Previous studies, despite their contribution to the discourse on Songgukri political economy, have not yet fully resolved the question whether a rigid hierarchy was indeed a key to the formation of the settlement relationships. For example, Kim (2014a) contested the earlier arguments for surplus extraction from non-centers (Grier and Kim 2012; Kim 2008) as both centers and non-centers revealed large-volume vessels possibly for storage. Bale (2017) also claimed that the storage facility alone cannot be equated to excess production without evidence for the regular surplus production of staples. Another remaining question is whether Songgukri inhabitants could have perceived an advantage to live in the centers for labor pooling and transportation, as suggested by Kim (2006c). Other studies indicate that key cultural practice (storage strategy, farming, craft production) occurred at the local household level through cooperation and collective decision making (Bale 2011, 2017; Bale and Ko 2006). It is currently unclear how this cultural practice fits in the hierarchical model of Songgukri settlement relationships.

\section{Songgukri landscape in the study area}

This study examines Songgukri settlements in the middle and lower reach of the Geum River, one of the four major river systems in Korea. Geum runs through moderate hills of the Charyung mountain range from east to west over the southwestern region (Fig. 1).

The landscape setting of Songgukri sites is divided into three types, foothill areas, hilltops, and alluvial plains (Lee 2016; Yun 2014). Most Songgukri settlements in our study belong to the first type. They are situated in relatively homogenous landscapes along the foothill regions of the Geum basin. Narrow flats near the settlements were probably saturated with streams running down from low hill ridges, and thus ideal for farming (Yun 2014). The Songgukri landscape was probably marked by settlements situated on foothills with higher hillslopes behind and water source and farmable flats in front, often facing another settlement with a similar landscape on nearby foothills (Lee 2000) (Fig. 2).

Such landscape probably provided Songgukri people several advantages, including flood protection, defensive and visibility advantages, farmable flats between hill ridges, and access to wild terrestrial resources from hillslopes behind. Baesanimsoo, one of the traditional Asian Fengshui principles, means the riverfront village with mountains behind. Such foothill areas have been historically considered an ideal place to live in Korea.

\section{Materials studied}

A total of 41 Songgukri settlement sites comprise the subject of this study. As with the majority of archeological fieldwork in Korea, most of the Songgukri settlements were investigated as rescue projects for housing or road construction. Since some areas of the region have not been subjected to as many developmental projects as others, the actual population of Songgukri settlements in the region is likely much higher. This study defines a settlement as a distinct archeological locality where at least one residential feature (a pit house) was found.

On the definition of central settlement, a general consensus is that central settlements have complex arrangements of specialized spaces such as residential, food and craft production, storage, and ritual areas, coupled with a large site extent (Bale 2017; Kim 2015a; Ko 2010; Lee 2009; Lee 2016). The underlying assumption herein is that central settlements were demarcated by specialized functions as large residential places. The site that satisfies this definition most clearly is Songgukri, the type site of the Songgukri culture. This site yielded more than 100 pit houses over a vast area ( 9.8 ha), the largest number found among all in the Geum River basin region. Moreover, the extensive defensive structures and two large raised floor buildings found at the site provided its residents a protection and communal space (Archaeology Center of Korea National University of Cultural Heritage 2011). The finding of jade crafts and other prestigious burial offerings, most notably Liaoning-style bronze daggers, also indicates the social and political importance of the Songgukri site in the region (Ahn and Kim 1975; Son 2007).

The presence of other centers is less clearly established whereas the Songgukri site is almost unanimously regarded as a central or at the very least important settlement (Bale 2017; Kim 2006d; Kim 2008; Lee 2009; Lee 2016; Lee and Bale 2016). Using the characteristics of the Songgukri center described above, we identified two potential centers, the Dosamri and Nabokri sites. Both have the second- and the third-highest number of pit houses respectively, and complex features, including a possible elite residence, mortuary ritual spaces, and food storage features. They were also identified as "lower-tier centers" by previous regional settlement studies (Kim 2005, Kim 2006d). By comparing these three centers against all other 38 sites, we will check whether the landscape visibility will reveal the settlement relations between the two tiers.

\section{Viewshed size}

Viewshed size is a measure of visibility that directly corresponds to the extent of one's area of visibility (Lake and Ortega 2013). Inhabitants of settlements with larger viewsheds could overlook a broader landscape than those 


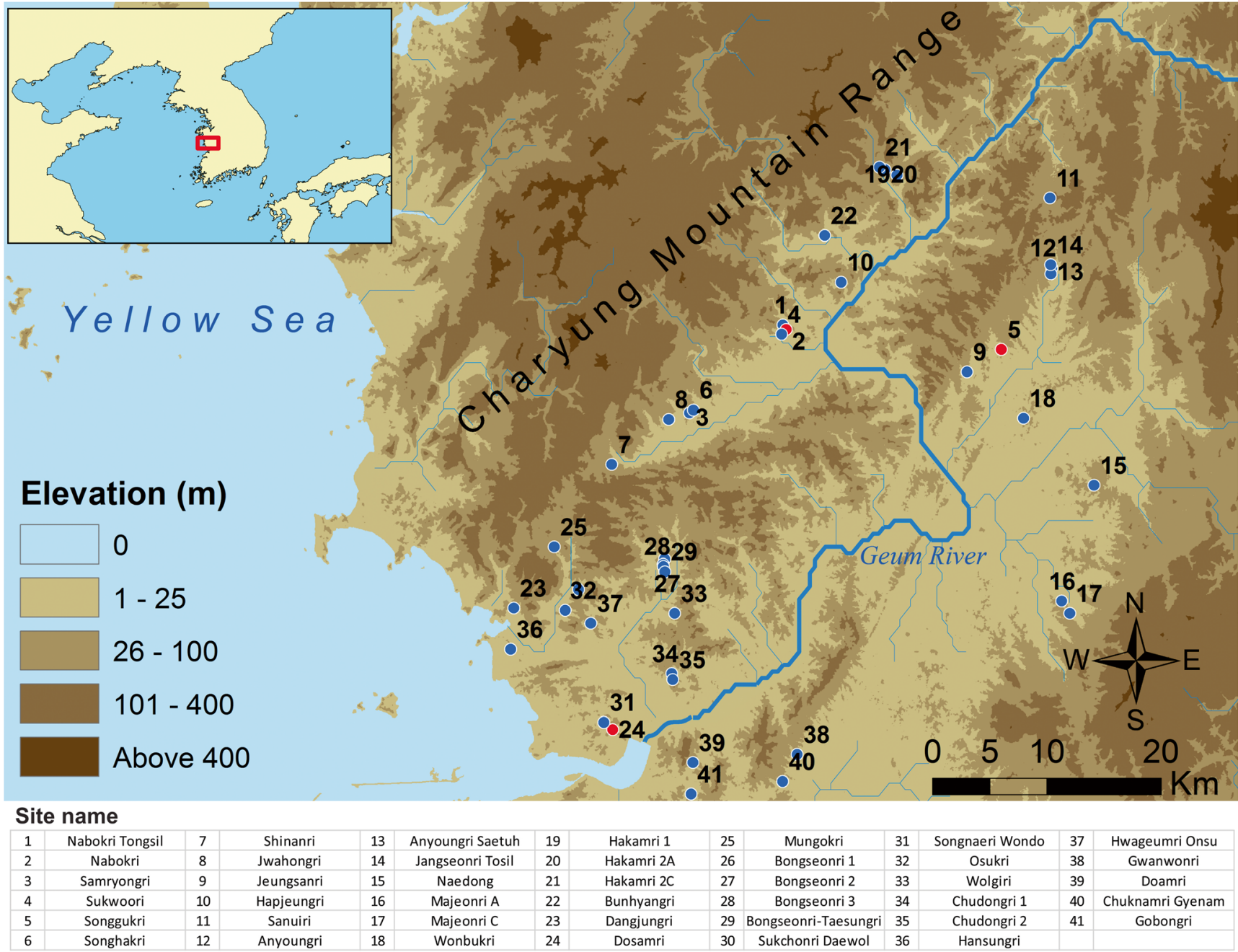

Fig. 1 Map of the study area and the Songgukri settlement locations (red, centers; blue, non-centers)

living in settlements with smaller viewsheds. Our calculation of viewshed size is based on viewshed analysis, a commonly employed geographical information system (GIS) method in

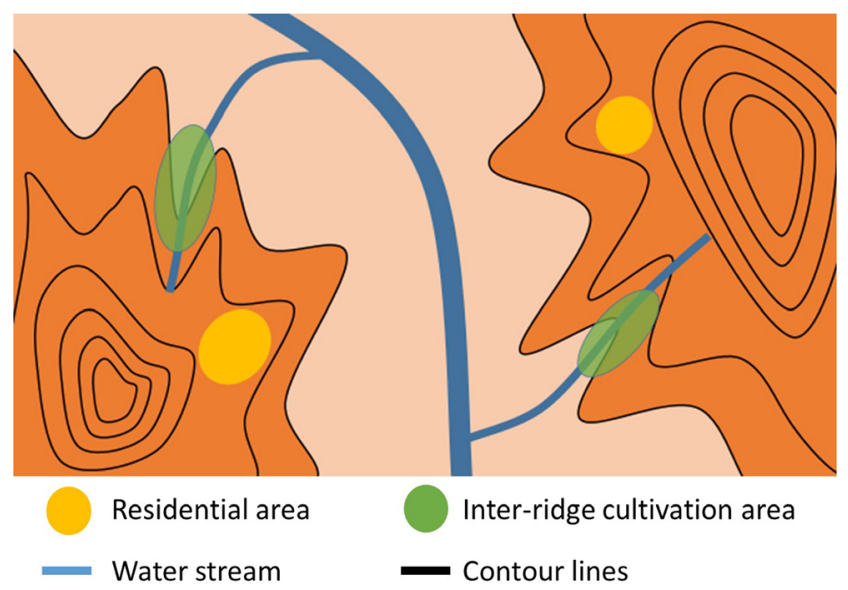

Fig. 2 Schematic bird's-eye view of the Songgukri settlement landscape in the study area archeology (Eve and Crema 2014; Jones 2006; Jones and Wood 2012; Kosiba and Bauer 2013; Sakaguchi et al. 2010; Wheatley 1995). Viewshed analysis can identify the visible area from a particular observer point by determining whether a line-of-sight can be drawn from that point to a target location without being obstructed by terrains. In GIS-based operations, viewshed analysis is performed on a grid-cell model of the landscape, often referred to as the digital elevation model (DEM). Every cell in the DEM contains an elevation value at the particular location of the cell. Using elevation differences between the cell(s) designated as the observer point(s) and all other cells, the viewshed analysis produces a binary output of cells either as being visible from the observer point (and thus a value of 1) or not (0) (Fig. 3).

After deriving the viewshed, its size is calculated by counting the number of visible cells within a pre-defined bounding radius of each observer point and then multiplying the cell count by the cell dimension of the DEM. Our viewshed analysis is performed on $30 \mathrm{~m}$ resolution DEM, obtained by the Shuttle Radar Topography Mission (SRTM) 
Fig. 3 Viewshed analysis on DEM. The dotted line represents an obstructed line of sight

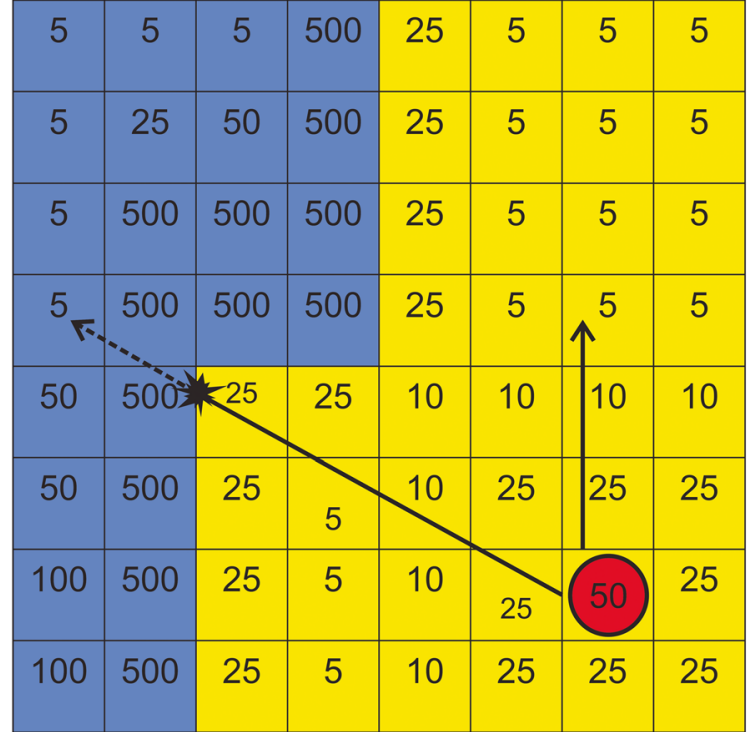

$\square$ Visible

Not visible

Observation
point

Values in cells represent elevation $(m)$
(NASA Jet Propulsion Laboratory 2013). We used each Songgukri settlement location as an observer point and calculated the viewshed size at each settlement. Two bounding radii sizes, $16 \mathrm{~km}$ and $4 \mathrm{~km}$, have been used for the calculation of viewshed size to gauge how parameterization of visibility distance limit influences the output of the analysis. The $16 \mathrm{~km}$ radius represents the maximum distance of visibility of human sight that automated weather observation stations in US airports use (National Oceanic and Atmospheric Administration 1995). Approximately, the $10 \mathrm{~km}$ is the lower 25 th percentile visibility of contemporary urban centers in Korea with anthropogenic air pollution (Lee et al. 2015). The $4 \mathrm{~km}$ radius therefore represents a very conservative limit of human visibility when non-optimal atmospheric conditions inhibit human visibility. We applied a two-sample $t$ test on the viewshed sizes of the centers and non-centers for both bounding radii to check a statistical significance with a $p$ value less than 0.05 .

Our viewshed analysis masked the ocean space (the Yellow Sea) so that the area would be excluded from the viewshed of each settlement. The impact of masking will be a slight underestimation of the viewshed size of settlements near the coast. Since SRTM takes the elevation of earth's features at the surface, the sea areas are represented as a "flat plain" of 0 m elevation cells in the study's DEM. Lacking terrain features that can obstruct line-of-sight, the sea areas will be visible by coastal settlements at a very high rate, thereby contributing a significant overestimation of the viewshed size of coastal settlements against inland ones. The masking of sea areas is therefore necessary to prevent the bias influencing the result of the analysis.

One methodological limitation inherent in the standard viewshed analysis is that it uses a single arbitrary point as the point of observation (Wheatley and Gillings 2000). Often, archeological studies abstract the locations of past observers into an arbitrary point inside a site area (e.g., Brughmans et al. 2015; Jones 2006; Wright et al. 2014). This practice is potentially problematic, because past observers cannot be represented as a fixated point on a landscape. That is, archeological sites have spatial dimensions, and the observers in this space would have been capable of moving. Thus, viewshed analysis based on a single arbitrary cannot represent a comprehensive picture of landscape visibility available to past observers.

To address this concern, we modified the standard viewshed analysis to incorporate a degree of comprehensiveness to the viewsheds of each settlement. First, we created four circular buffers with radii of $1 \mathrm{~m}, 50 \mathrm{~m}, 100 \mathrm{~m}$, and $200 \mathrm{~m}$ around an arbitrary point within each settlement location. Each buffer represents different areal extents for observers' everyday mobility. Then, we used all cells on the DEM that intersected with the circumferential boundary of these buffers as observer points and derived the viewshed at these cells. Our modified viewshed method offers a more comprehensive and realistic picture of landscape visibility, compared with the standard viewshed based on a single arbitrary point. For example, the standard viewshed based on a point in the 57 th locality of the Songgukri site fails to show an apartment complex as visible, although we were able to see it from various locations within the site. Similarly, the standard viewshed does not indicate that the 45th locality of Songgukri is visible when the locality is part of the site landscape. In contrast, our modified viewshed correctly identifies both the apartment complex and the 45th locality as visible (Fig. 4).

\section{Shared-ness of viewshed}

We devise a new measure of visibility and termed the "sharedness of viewshed (SoV)" to indicate how much landscape 


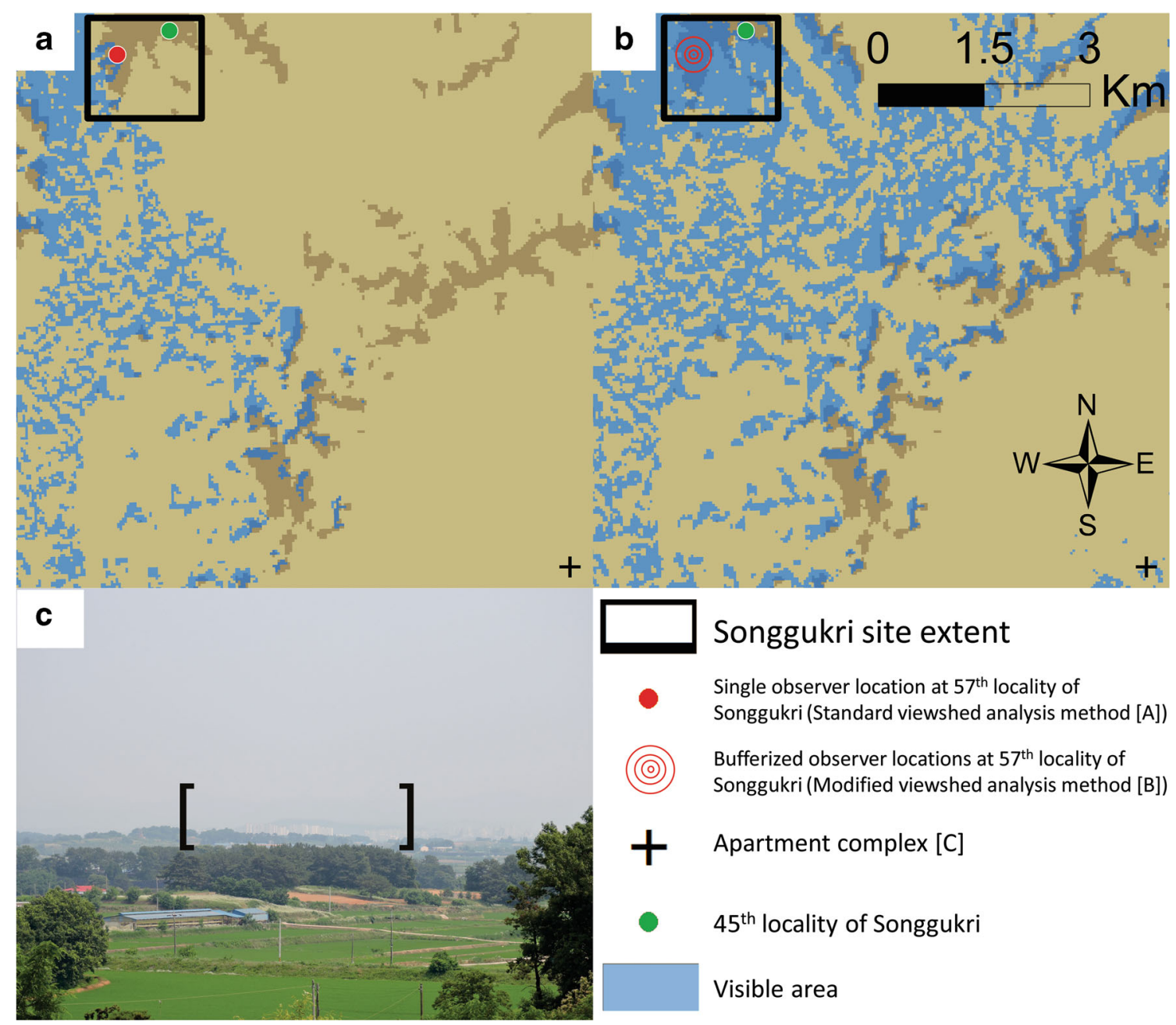

Fig. 4 Comparison of the standard viewshed (a) and the study's modified viewshed method (b) at the Songgukri site, using observable landscape visibility components (an apartment complex and 45th locality of Songgukri). c An apartment complex visible from Songgukri

visible at one settlement is shared by others. We calculated the SoV by a series of raster (grid-cell) algebra on the viewshed of each settlement and the cumulative viewshed. As its name suggests, the cumulative viewshed sums all the viewsheds at multiple observer locations (Llobera 2003). A numeric value of each cell in the cumulative viewshed corresponds to the number of observers who can see that particular cell. For example, a cell with a value of "2" means that this particular cell is visible by two different observers.

We calculated the SoV by the following method. First, we added the viewsheds of the 41 Songgukri settlements into the cumulative viewshed. Then, we decided a value for $n$, the number of settlements capable of seeing a particular cell. Since the SoV by definition requires at least two settlements to mutually share portions of their own visible landscape, the value of $n$ must be an integer greater than or equal to 2 . The greater the value of $n$, the harder it is for all settlements involved to mutually share their visible landscape. In our study, we use 2 and 3 as the value of $n$ to gauge how the parameterization of $n$ (the number of settlements sharing visible landscape) influences the result of the analysis. We conditioned cell values of the cumulative viewshed, so cell values greater than or equal to $n$ were converted to 1 (true), and those lower than $n$ became 0 (false). The resulting output would be a conditioned cumulative viewshed that indicates cells visible by at least $n$ number of settlements as 1 and those less than $n$ as 0 (Fig. 5(1)).

Next, we multiplied the conditioned the cumulative viewshed by the original viewshed at each settlement. The output of these algebraic calculations is a set of binary gridcells, or the "shared viewshed," which indicates whether a cell visible at a particular settlement is also visible by at least $n$ settlements (Fig. 5(2)).

Finally, we calculated the size of the "shared viewshed" within $16 \mathrm{~km}$ and $4 \mathrm{~km}$ radii and divided the resulting "shared viewshed" size by the size of the original viewshed at each settlement. Then, the resulting ratio indicates how much viewshed at a particular settlement is shared by other settlement(s). For example, the $\mathrm{SoV}$ ratio of 0.6 when $n$ is 2 within the $16 \mathrm{~km}$ bounding radius indicates that $60 \%$ of the site's 

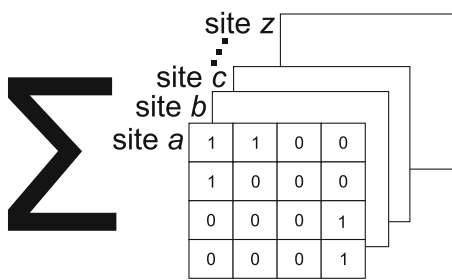

summing all sites' original viewsheds from site a to $Z$ (cell value $1=$ 'visible'; $0=$ 'not visible)
Let $n$ be an integer $\geq 2$,

which notes the

number of sites capable of seeing a certain cell

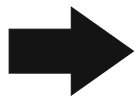

Conditioning:

if cell values are

$\geq n$ then convert to 1 (true) if $<n$ then convert to 0 (false)

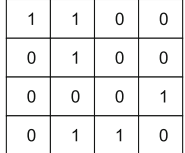

conditioned cumulative viewshed

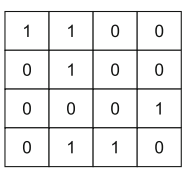

conditioned cumulative viewshed
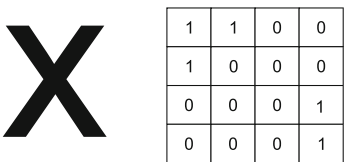

original viewshed at site $a$

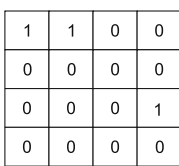

$(2)$

'shared viewshed' at site $a$

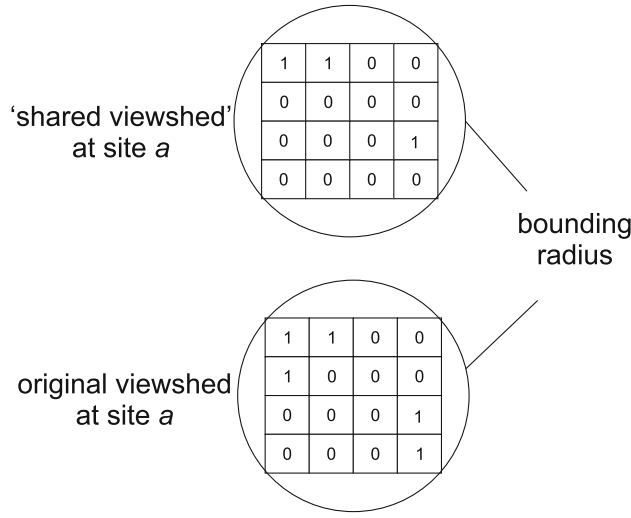

Fig. 5 Order of operations for deriving the shared-ness of viewshed the size of the

'shared viewshed'

at site $a$

cell value count for the viewshed size calculation
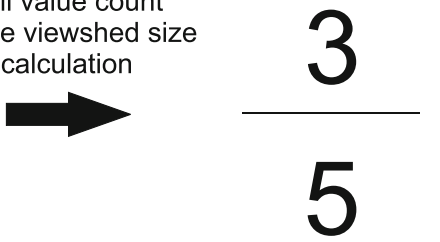

the size of the original viewshed at site $a$
0.6

the ratio of which the site a's viewshed is shared by at least $(n-1)^{*}$ other site(s)

*shared between the original site $a$ and at least one other sites visible landscape is also visible by at least one other settlement (Fig. 5(3)). After SoV ratios are calculated for $16 \mathrm{~km}$ and $4 \mathrm{~km}$ radii, we again applied a two-sample $t$ test on SoV ratios of the centers and non-centers for both bounding radii to check a statistical significance with a $p$ value less than 0.05 .

\section{Results}

\section{Viewshed size}

Our analysis indicates that the viewshed size of Songgukri settlements varies considerably with a slight skewness towards to the left (a lower viewshed size) regardless of the bounding radius size (Fig. 6; Table 1). The variation of viewshed sizes does seem to be affected by the center/noncenter distinction since the two-sample $t$ test indicates $p$ value less than 0.001 and 0.031 , respectively, for $16 \mathrm{~km}$ and $4 \mathrm{~km}$ radius. Within the $16 \mathrm{~km}$ radius, all of the central settlements have a viewshed size larger than the upper 25 th percentile. The same is true within the $4 \mathrm{~km}$ bounding radius at
Songgukri and Nabokri, but not at Dosamri. Dosamri still has a viewshed size above the median, and as it is located near the coast, its viewshed size may have been underestimated. In summary, the viewshed analysis supports our hypothesis: central settlements do tend to have greater landscape visibility than non-centers.

\section{Shared-ness of viewshed}

The ranges of the SoV suggest that all Songgukri settlements tend to have highly shared visible landscapes (Fig. 7; Table 2). This is again true regardless of the different bounding radius sizes although the SoV is slightly higher with the $16 \mathrm{~km}$ radius than the $4 \mathrm{~km}$. The settlement at the median shared $83 \%$ or $71 \%$ of its visible landscape with at least one more settlement within $16 \mathrm{~km}$ or $4 \mathrm{~km}$ radius, respectively. Even when we increase the threshold of shared visibility by two sites $(n=$ 3 ), the settlement at the median shared $58 \%$ or $35 \%$ of its visible landscape by at least two others in each radius.

The center/non-center distinction does not seem to affect the SoV in contrast to the viewshed size. The two-sample $t$ test 


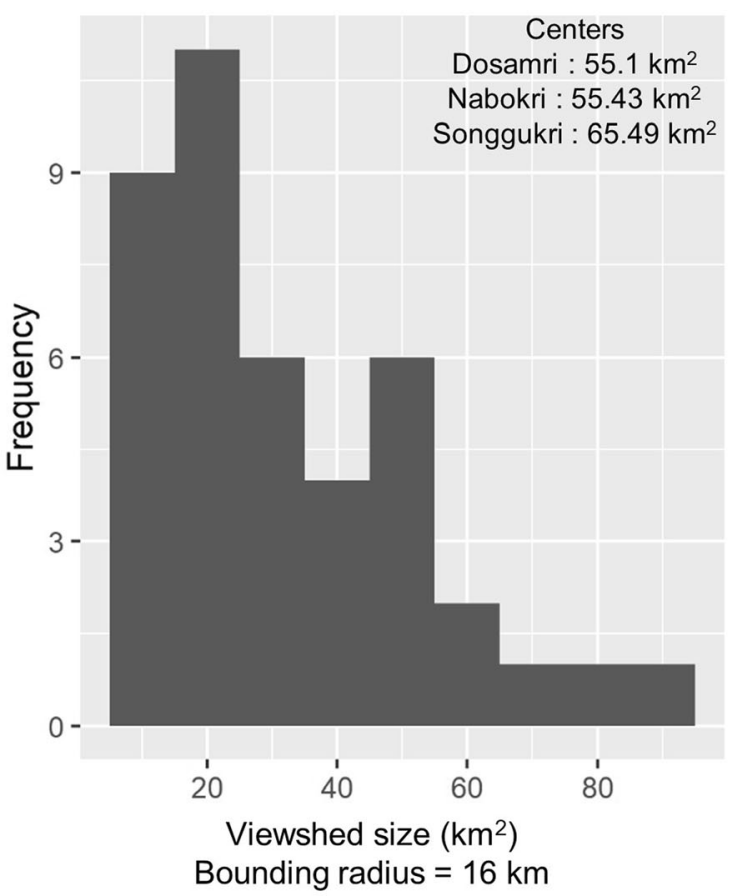

Fig. 6 Histograms of viewshed size at Songgukri settlements

indicates a $p$ value much greater than 0.05 , regardless of any sets of parameters (bounding radii, $n$ ). This indicates that the $\mathrm{SoV}$ analysis does not support our working hypothesis. No clear disparity between the Songgukri centers and noncenters was detected in the measure of shared visual space.

\section{Discussion and conclusion}

\section{Beyond the center vs non-central settlement hierarchy}

The result of our analyses only partially supports the expectations of our working hypothesis. While Songgukri centers tend to have larger landscape visibility than non-centers, the extent of the shared visible space is not statically different between the two tiers. Sharing of the visible space between the two can be understood in terms of resource and labor pooling relationships. The high rate of shared visible space in both tiers cannot be adequately understood by the concept of hierarchical settlement organizations. We therefore seek alternative interpretations of landscape visibility beyond the common view.

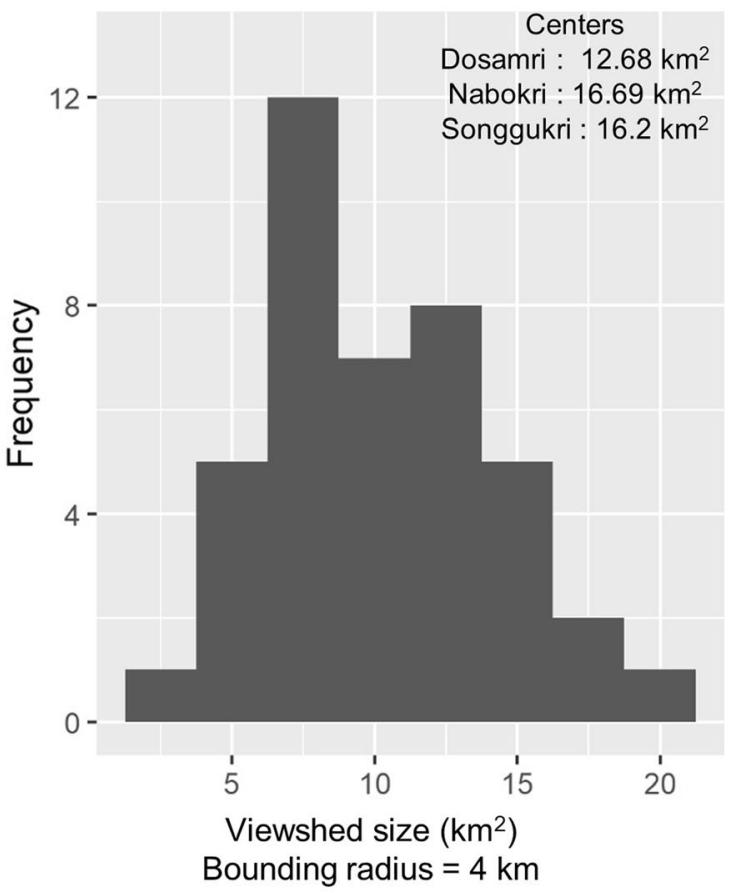

In applying the visibility analysis, we are aware that GIS can overlook the complex temporal nature of archeological data (Gupta and Devillers 2016). For example, a study on prehistoric barrow clusters in southern England shows that a temporal dimension is a key to understanding an emerging visibility network (Tilley 1994). The study showed that the establishment of prominent barrows attracted the later construction of barrows over a prolonged time. Similarly, Brughmans et al. (2015) demonstrated that patterns of settlement visibility emerged over a long time among Iron Age and Roman settlements in southern Spain.

Taking a cue from these studies, we seek a temporal dimension of visibility as an essential concept in explaining settlement relationships. We emphasize a long-term bottom-up process of cultural interactions that enabled Songgukri settlement groups to form cultural belonging over time. This perspective is sometimes glossed by the concept of "interaction spheres." This concept has been used in cultural analysis to explain the nature of flows of ideas and goods among societies (Caldwell 1964). The theoretical advantage of this notion is that it does not put forward social inequality as a priori condition for socioeconomic interactions. The popularity of interaction sphere models as an analytic tool in archeology gave way to the
Table 1 Distribution of viewshed size at Songgukri settlements, units in $\mathrm{km}^{2}$

\begin{tabular}{ccccccc}
\hline $\begin{array}{l}\text { Bounding } \\
\text { radius }\end{array}$ & Min & $\begin{array}{l}\text { 1st } \\
\text { quartile }\end{array}$ & Median & $\begin{array}{l}\text { 3rd } \\
\text { quartile }\end{array}$ & Max & $\begin{array}{l}\text { Center vs non-center significance test } \\
(p \text { value })\end{array}$ \\
\hline $16 \mathrm{~km}$ & 6.56 & 15.25 & 26.04 & 45.90 & 91.68 & $<0.001$ \\
$4 \mathrm{~km}$ & 3.13 & 6.94 & 10.65 & 12.74 & 21.02 & 0.031 \\
\hline
\end{tabular}



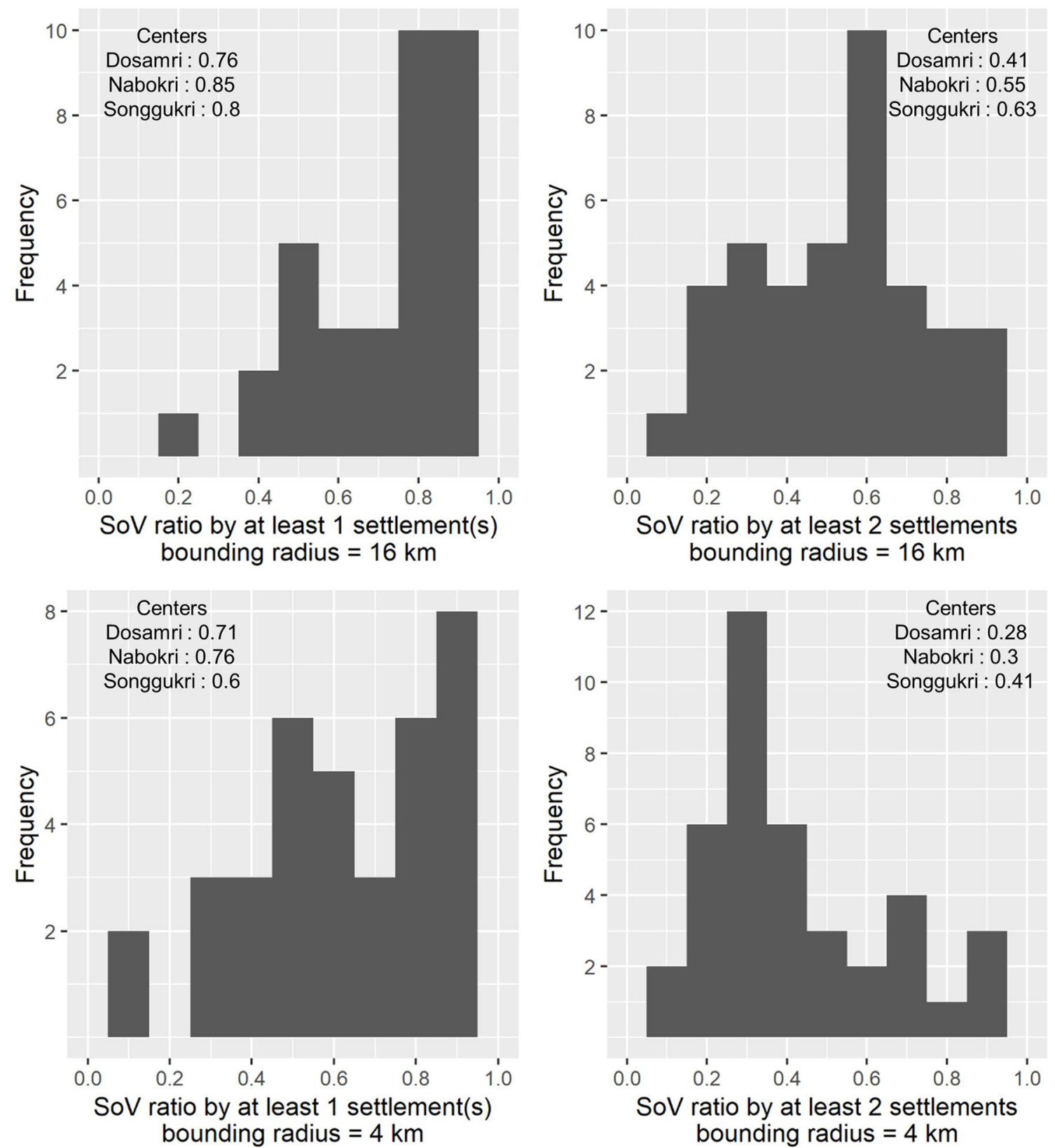

Fig. 7 Histograms of shared-ness of viewsheds (SoV) at Songgukri settlements

cultural evolutionary theory in the 1960s and 1970s (Oka and Kusimba 2008). However, interaction sphere still can offer important theoretical insights to the study of complex societies, particularly those which do not clearly exhibit signs of vertical social inequality. Stein 2010; Stein 2014 are insightful examples of how the interaction spheres could be used
Table 2 Distribution of sharedness of viewsheds (SoV) ratio at Songgukri settlements

\begin{tabular}{llllllll}
\hline $\begin{array}{l}\text { Bounding } \\
\text { radius }\end{array}$ & $\begin{array}{l}\text { SoV by at least } n \text { other } \\
\text { settlement(s) }\end{array}$ & Min & $\begin{array}{l}\text { 1st } \\
\text { quartile }\end{array}$ & Median & $\begin{array}{l}\text { 3rd } \\
\text { quartile }\end{array}$ & Max & $\begin{array}{l}\text { left vs non-left } \\
\text { significance test } \\
(p \text { value })\end{array}$ \\
\hline $16 \mathrm{~km}$ & 1 & 0.17 & 0.61 & 0.83 & 0.92 & 0.99 & 0.335 \\
$16 \mathrm{~km}$ & 2 & 0.13 & 0.4 & 0.58 & 0.7 & 0.97 & 0.765 \\
$4 \mathrm{~km}$ & 1 & 0.13 & 0.48 & 0.71 & 0.90 & 0.99 & 0.716 \\
$4 \mathrm{~km}$ & 2 & 0.05 & 0.28 & 0.35 & 0.56 & 0.95 & 0.119 \\
\hline
\end{tabular}


as a unit of analysis in explaining social interactions in the Ubaid culture in Southwest Asia. He showed that the Ubaid material culture is not homogeneous. Rather, the stylistic forms and ideological structures of the Ubaid were shared among different regional communities to varying degrees. Its symbolic vocabulary, embedded in the shared material culture, reproduced a common set of the values and beliefs that contributed to the local communal belonging in the Ubaid interaction sphere (Stein 2014). The emergence of communal belonging has been overlooked in the popular models of homogenizing chiefdoms. We redraw the attention to this important aspect of social organization by hypothesizing that the Songgukri people experienced the cultural belonging by their shared visible landscape.

Let us imagine a moment when Songgukri settlements were about to be established in the Geum River basin. The Songgukri people would have chosen a place that granted them visual advantages over the vicinity for a variety of reasons, including management of resources and defensive advantages. As time passed by, these early settlements likely experienced population growth, became a hub of diverse activities, and matured into prominent settlements, possibly centers. Processes of population growth and increasing organizational complexity have long been recognized as part of the urban growth process (Bettencourt et al. 2007; Burgess 1925). A correlation of the population level to the organizational complexity in settlements, particularly administrative natures, has also been observed in other archeological contexts (Blanton and Fargher 2008; Feinman and Neitzel 1984). The process of Songgukri settlement growth would not have been very different on a fundamental level. The growth of early settlements and the establishment of new settlements through fissioning would have been simultaneous. Newer settlements may have been formed by the "budding" population from an established settlement or by new immigrants coming into the area. A fissioning rate of settlements is known to be correlated negatively with the level of social integration by higher-level institutions. These institutions include strong leaderships or religious traditions, which are capable of mitigating in-group conflicts (Alberti 2014; Bandy 2004). The chiefdom model that sees the society is integrated around powerful elites. If we disentangle our explanation from this emphasis, then we can expect that the fissioning rate of Songgukri settlements could have been relatively high.

Such rapid growth and expansion of the Songgukri culture are well attested with archeological evidence (Park 2015). Songgukri settlements of various extents and structures appeared beyond the Geum River after its initial appearance around $2900 \mathrm{cal}$. BP. If people in old and new settlements longed for a sense of belonging, visibility would have a powerful reminder of their relatedness. And thus, newer settlements may have situated themselves in a way that they shared part of the existing settlement's visible landscape.
Archeologists have long been recognizing that spatial and social relations are closely linked (e.g., Chang 1958; Joyce and Hendon 2000; Trigger 1967). This premise is at the core of the reason why they pursue the analysis of space for social inferences (Ashmore 2002). Ethnographic and archeological studies worldwide also demonstrate that people tend to construct their living environment such that the physical distances between dwellings closely reflect the social distances of the dwellers (Wiseman 2016). Under such findings, we propose that sharing a landscape through visibility was probably an important cultural mechanism for the Songgukri settlers. By sharing the landscape visibly, they could have constructed a cultural space for groups of people closely tied with marriage, trade, labor cooperation, or other forms of social interactions. We suggest that a cultural belonging emerged from this longterm cultural interactions may be crucial to understanding the general shared-ness of landscape visibility among Songgukri settlements.

\section{A shared sense of cultural belonging among Songgukri settlers}

Aside from the similarity of material culture, the evidence for cultural belonging among Songgukri settlers may be found in the organization of space for dwelling. Scholars note that dwelling areas (i.e., house floor) of Songgukri-type houses are significantly reduced in size from those of the Early Mumun period (3300-2800 cal. BP) (Kim 2015a; Lee and Bale 2016). This reduction of dwelling space is often regarded as the evidence for a shift from a multi-family to a singlefamily household organization at the onset of Songgukri culture (Kim 2015a). Songgukri-type houses are often found in clusters of three to five, and each cluster likely formed an extended household in which members shared certain activities. This household organization is also indicated by the arrangements of outdoor hearths and storage pits. This evidence signifies that kin relationships of Early Mumun households were maintained in Songgukri households despite the architectural changes (Lee and Bale 2016). Lee (2003) suggested that the Songgukri architectural arrangements may reflect the communal practice of sharing space for daily meal preparation outside the individual households. She suggested such communal practice of building cohesions was a countermeasure of social differentiations when collective efforts were needed more than ever in intensive farming and organized labor projects (e.g., palisades, megalithic burials).

One of the defining characteristics of the landscape visibility pattern among Songgukri settlements is the general sharedness of their visible landscape. Our analyses indicate that the visual world of Songgukri inhabitants, no matter at which settlement they stood, had a very high likelihood of being mutually acknowledged and experienced by the dwellers of neighboring settlements. Passive gazing was probably not the 
only means by which Songgukri settlers visually shared their landscape. People's everyday activities could enhance Songgukri people's mutual understanding that people akin to them live "out there." The smoke generated by domestic cooking or the light from night lamps could have allowed them to see and to experience each other's existence.

The Songgukri centers are located on the hilltops or hillslopes, overlooking plains with a wide-open vista. These centers could be easily visible from other peripheral settlements in the vicinity. Kim (2006a) sees this inter-settlement visibility as a means of boosting a shared sense of community, a base of the elite's exertion of power and authority. According to Sahlins (2013:20), a kinship system is a "network of mutualities of beings." Songgukri people may have formed and maintained close kin relationships through the mutual acknowledgment that they live in a shared space and time. This kinship formation may have been analogous to the process by which Songgukri households kept their relationships in separate but shared dwelling spaces.

\section{Connecting the dots}

The Songgukri settlement relationships that were reflected from our analysis contrast with the one suggested by the chiefdom model. The chiefdom model understands the settlement relationships through a top-down hierarchy where the elites in centers subjugate others in the periphery. Our emic perspective puts forth the bottom-up process in which the settlement relationships were organically evolved through a sense of shared cultural belonging. These two views, however, do not necessarily invalidate each other. Egalitarian ethos can not only coexist with hierarchies of control but also reinforce inequality and dominance (Brumfiel 1995). Kim (2006c) also emphasized mixed political strategies of top-down control and bottom-up cooperation in the Songgukri agricultural economy.

Further ahead, our emic perspective on Songgukri settlement relationships allows us to formulate a coherent narrative about their cultural practice, including storage strategy, agricultural practice, and craft production - the dots that are left unconnected by the chiefdom model. Bale (2017) suggested that large-capacity vessels, pits, and raised-floor structures were maintained as storage space at the household level for self-reliance over the long term. Thus, he rejected the assumption that storing surplus by Songgukri households was the elites' strategy of controlling the resource produced by the non-elites.

Bale (2011) also examined the spatial orientations of farming fields at the Daepyongri site along the Nam River in southcentral Korea, contemporaneous to Songgurki. He observed that some dryfields were spatially associated with distinctive pit house clusters. The fields appear to be regularly refurbished that probably requires close local coordination over the long period. He further suggested that various decisions involved with farming were made at the local-level by household groups rather than by the elite's top-down coercive force. This argument is also echoed by Kim (2006c) in his equal emphasis on both elites' managerial roles and household-level cooperation in the Songgukri political economy. By analyzing plant remains, Kim (2015b) and Lee (2003) reached a similar conclusion that agriculture reinforced communal cooperation in Songgukri culture.

Bale and Ko (2006) indicated that Songgukri elites did not have significant control over prestigious craft production in the Daepyongri site since craft production did not take place near the elite residence. Instead, prestigious crafts appear to be produced by part-time specialists living in common pit houses. Consumption of prestigious crafts was, however, concentrated in the innermost ditch-and-palisade precinct, which was proposed as the stage for communal ceremonial activities (Bale and Ko 2006). In this setting, prestigious crafts were used as regalia in group-oriented ceremonies by elite actors to deemphasize the bulging social difference and to increase the ideological preemption of the elites.

The studies on storage strategy, agricultural practice, cooking customs, and craft production all share a common denominator in their emphasis on cooperation, cohesions, and local decision-making processes in various aspects of Songgukri cultural life. In order to operate communal cooperation and decision-making effectively under a certain degree of egalitarian ethos, Songgukri communities would have had recognized each other not as "others" but as "one of us." A sense of cultural belonging, reinforced through their shared landscape visibility, may have provided a firm ground on which Songgukri people could have established their shared identities.

\section{Conclusion and future direction}

This study examines the settlement relationships of the Songgukri culture in the Geum River basin, using various analyses on landscape visibility. Our non-hierarchical settlement organizational framework reflects that Songgukri culture shared a mutual acknowledgment of living in a common time and space - a sense of cultural belonging. We emphasized the importance of the bottom-up and long-term perspective to grasp how such cultural foundations and social dynamics emerged across the Songgukri settlements.

While Songgukri settlements in the Geum River basin have been the focus of this study, the Songgukri culture expanded widely beyond the Geum River basin. Songgukri settlements in other regions vary in terms of their landscape settings and resource distributions. Such regional variability in settlement organization and interaction remains unexplored. At present, the regional variability is only accounted by the typological comparison of artifacts and residential features. Moving 
forward, we plan to conduct similar analytical research outlined here to reveal the spectrum of sociopolitical and cultural underpinnings of the Songgukri culture beyond the Geum River basin.

Acknowledgments We thank Dr. Hopil Yun at the Sangju Museum for his participation in our field survey and for sharing his insight. Our gratitude is to Dr. Rory Walsh at University of Michigan and Hyunsoo Lee at University of Oregon for their comments on earlier drafts of this version. We would like to express our appreciation to Dr. Hongjong Lee, Dr. Junho Son, and Sunghee Park at the Korea University for providing us access to the site data used in this study. Finally, we thank two anonymous reviewers for their constructive comments that helped us improve the quality of the paper.

Funding information This work was supported by the Korean Studies Promotion Service/Academy of Korean Studies under the Laboratory Program Grant for Korean Studies (AKS-2015-Lab-2250001).

\section{Compliance with ethical standards}

Conflict of interest The authors declare that they have no conflicts of interest.

Open Access This article is licensed under a Creative Commons Attribution 4.0 International License, which permits use, sharing, adaptation, distribution and reproduction in any medium or format, as long as you give appropriate credit to the original author(s) and the source, provide a link to the Creative Commons licence, and indicate if changes were made. The images or other third party material in this article are included in the article's Creative Commons licence, unless indicated otherwise in a credit line to the material. If material is not included in the article's Creative Commons licence and your intended use is not permitted by statutory regulation or exceeds the permitted use, you will need to obtain permission directly from the copyright holder. To view a copy of this licence, visit http://creativecommons.org/licenses/by/4.0/.

\section{References}

Ahn J-H (2004) The comparison of a settlement at the Middle Bronze Age. J Kor Ancient Histl Soc 43:1-24 In Korean with English abstract

Ahn S-J, Kim Y-B (1975) Buyeo songgukri yonyeongsik donggeom chulto seokgwanmyo. Paekchemunhwa 7-8:7-29 In Korean

Alberti G (2014) Modeling group size and scalar stress by logistic regression from an archaeological perspective. PLoS One 9(3):e91510

Amidon E, Elsner G (1968) Delineating landscape view areas: a computer approach. Forest Research Note PSW-180. US Department of Agriculture, Washington, DC

Archaeology Center of Korea National University of Cultural Heritage (2011) Songguk-ri site VII: the 12th \& 13th field campaigns on Songguk-ri site in Buyeo. Archaeology Center of Korea National University of Cultural Heritage In Korean

Archaeology Center of Korea National University of Cultural Heritage (2013) Songguk-ri site VIII: the 14th field campaigns on Songguk-ri site in Buyeo. Archaeology Center of Korea National University of Cultural Heritage In Korean

Archaeology Center of Korea University (2004) Majeon-ri C site. Archaeology Center of Korea University In Korean
Ashmore W (2002) "Decisions and dispositions": socializing spatial archaeology. Am Anthropol 104(4):1172-1183

Bale M (2011) Storage practices, intensive agriculture, and social change in Mumun pottery period Korea, 2903-2450 calibrated years BP. Ph.D. thesis, Dept. of Anthropology, University of Toronto

Bale M (2017) An examination of surplus and storage in prehistoric complex societies using two settlements of the Korean peninsula. World Archaeol 49:1-15

Bale M, Ko M-J (2006) Craft production and social change in Mumun pottery period Korea. Asian Perspect 45:159-187

Bandy M (2004) Fissioning, scalar stress, and social evolution in early village societies. Am Anthropol 106(2):322-333

Bettencourt L, Lobo J, Helbing D, Kühnert C, West G (2007) Growth, innovation, scaling, and the pace of life in cities. Proc Natl Acad Sci 104(17):7301-7306

Blanton R, Fargher L (2008) Collective action in the formation of premodern states. Springer, New York

Brughmans T, Keay S, Earl G (2015) Understanding inter-settlement visibility in Iron Age and Roman Southern Spain with exponential random graph models for visibility networks. J Archaeol Method Theory 22:58-143

Brumfiel E (1995) Heterarchy and the analysis of complex societies: comments. In Ehrenreich R., Crumley C, Levy J (eds) Heterarchy and the analysis of complex societies. Archeological papers of the American Anthropological Association, no. 6, Washington, DC, pp. $125-131$

Burgess E (1925) The growth of the city: an introduction to a research project. In: Park R, Burgess E, McKenzie R (eds) The city. University of Chicago Press, pp 47-63

Chang KC (1958) Study of the Neolithic social grouping: examples from the new world. Am Anthropol 60(2):298-334

Caldwell J (1964) Interaction spheres in prehistory. In: Caldwell J, Hall R (eds) Hopewellian studies, scientific papers no 12. Illinois State Museum, Springfield, pp 133-143

Cummings V, Whittle A (2004) Places of special virtue: megaliths in the Neolithic landscapes of Wales. Oxbow Books, Oxford

Earle T (1987) Chiefdoms in archaeological and ethnohistorical perspective. Annu Rev Anthropol 16(1):279-308

Eve S, Crema E (2014) A house with a view? Multi-model inference, visibility fields, and point process analysis of a bronze age settlement on Leskernick Hill (Cornwall, UK). J Archaeol Sci 43:267277

Feinman G, Neitzel J (1984) Too many types: an overview of sedentary prestate societies in the Americas. Adv Archaeol Meth Theo 7:39102

Flannery K (1995) Prehistoric social evolution. In: Simon and Schuster education group (ed) research frontiers in anthropology. Needham Heights, Mass, pp 3-26

Grau Mira I (2003) Settlement dynamics and social organization in eastern Iberia during the Iron Age (eighth-second centuries BC). Oxf J Archaeol 22:261-279

Grier C, Kim J-S (2012) Resource control and the development of political economies in small-scale societies: contrasting prehistoric southwestern Korean and the Coast Salish region of northwestern North America. J Anthropol Res 68:1-34

Gupta N, Devillers R (2016) Geographic visualization in archaeology. J Archaeol Method Theory 24(3):1-34. https://doi.org/10.1007/ s10816-016-9298-7

Jones E (2006) Using viewshed analysis to explore settlement choice: a case study of the Onondaga Iroquois. Am Antiq 71:523-538

Jones E, Wood J (2012) Using event-history analysis to examine the causes of semi-sedentism among shifting cultivators: a case study of the Haudenosaunee, AD 1500-1700. J Archaeol Sci 39:25932603

Joyce RA, Hendon JA (2000) Heterarchy, history, and material reality: "communities" in late classic Honduras. In: Canuto M, Yaeger J 
(eds) The archaeology of communities: a New World perspective. Routledge, Abingdon, pp 143-160

Kim B-C (2005) Middle Bronze Age regional settlement patterns in the middle and lower reaches of the Geum River. J Kor Archaeol Soc 57:99-124 In Korean with English abstract

Kim B-C (2006c) Political versus subsistence economy of Songgukri culture in Chungnam Province. J Honam Archaeol Soc 24:65-96 In Korean with English abstract

Kim B-C (2006d) Household archaeology of Songgukri-type settlements in the lower and middle reaches of Geum River: analysis of household wealth/status variability using MDS. J Kor Anc Histl Soc 51: 79-108

Kim B-C (2014a) Understanding changes of domestic storage patterns in the bronze age, Hoseo region. J Kor Ancient Histl Soc 83:53-68 In Korean with English abstract

Kim B-C (2015a) Socioeconomic development in the Bronze Age: archaeological understanding of the transition from the Early to Middle Bronze Age, South Korea. Asian Perspective 54:144-184

Kim G-J (2010b) A study on the pattern of the acceptance and development of Songgukri-type culture on Jeju Island. J Kor Bronz Cult 6: 53-89 In Korean with English abstract

Kim G-T (2014b) The emergence of complex society in the Korean Bronze Age: focusing on Songgukri site in Buyeo. J Honam Archaeol Soc 46:5-24 In Korean with English abstract

Kim J-I (2006a) Theoretical characteristics and applicability of landscape archaeology. J Kor Archaeol Soc 58:110-145 In Korean with English abstract

Kim J-S (2008) Socioeconomic implications of storage facilities of the Songgukri period. J Kor Archaeol Soc 67:4-39 In Korean with English abstract

Kim M-K (2015b) Rice in ancient Korea: status symbol or community food? Antiquity 89(346):838-853

Kim S-O (2006b) The development and regional interactions of Songgungni-type assemblages in Korea. J Honam Archaeol Soc 24:33-64 In Korean with English abstract

Ko M-J (2010) A study of the settlement structure in the Nam River region during the Late Bronze Age. Yeongnam Archaeol Rev 54: 5-42 In Korean with English abstract

Kosiba S, Bauer A (2013) Mapping the political landscape: toward a GIS analysis of environmental and social difference. J Archaeol Method Theory 20:61-101

Kwak S-K, Kim G-T, Lee G-A (2017) Beyond rice farming: evidence from central Korea reveals wide resource utilization in the Songgukri culture during the late-Holocene. The Holocene 27(8): 1092-1102

Lake M, Ortega D (2013) Compute-intensive GIS visibility analysis of the settings of prehistoric stone circles. In: Bevan A, Lake M (eds) Computational Approaches to Archaeological Spaces. Left Coast Press, California, pp 213-242

Lee C-H (2011a) The principles and application of radiocarbon dating (II): archaeological application and instances. J Kor Archaeol Soc 81:269-291 In Korean with English abstract

Lee C-K (1988) Namhanjibang mumuntogi munhwa ui jeongae wa gongryeoltogi munhwaui wichi. J Kor Ancient Histl Soc 1:37-92 In Korean

Lee G-A (2003) Changes in subsistence systems in southern Korea from the Chulmun to Mumun Periods: archaeobotanical investigation. Ph.D. thesis, Dept. of Anthropology, University of Toronto

Lee G-A (2011b) The transition from foraging to farming in prehistoric Korea. Curr Anthropol 52:S307-S329

Lee H-J (2004) The landscape examination of Songguk-ri type settlement. J Hoseo Archaeol Soc 9:113-132 In Korean with English abstract

Lee H-J (2006) Absolute dates of Mumun and Yayoi pottery. J Kor Archaeol Soc 60:236-258
Lee H-J (2007) Space arrangement of the Songguk-ri type settlements. J Hoseo Archaeol Soc 17:114-133 In Korean with English abstract

Lee H-W (2009) Cheongdonggi sidae chwirak gujo wa sahoejojik. Seogyoung-mun-hwa-sa. In Korean

Lee J-C (2016) A study on the development and settlement systems of the Songguk-ri type culture in the Korean Bronze Age. Jininjin. In Korean

Lee J-Y, Jo W-K, Chun H-H (2015) Long-term trends in visibility and its relationship with mortality, air-quality index, and meteorological factors in selected areas of Korea. Aerosol Air Qual Res 15(2): 673-681

Lee R, Bale M (2016) Social change and household geography in Mumun period South Korea. J Anthropol Res 72:178-199

Lee S-G (2000) Cheongdonggisidae uiryee gwanhan gogohakjeogyeonggu. Ph.D. thesis, Dept. of History, Daegu Catholic University, Gyeongsan. In Korean

Llobera M (2001) Building past landscape perception with GIS: understanding topographic prominence. J Archaeol Sci 28(9):1005-1014

Llobera M (2003) Extending GIS-based visual analysis: the concept of visualscapes. Int J Geogr Inf Sci 17:25-48

Lock G, Harris T (1996) Danebury revisited: an English Iron Age hillfort in a digital landscape. In: Aldenderfer M, Maschner H (eds) Anthropology, Space, and Geographic Information Systems. Oxford University Press, Oxford, pp 214-240

Murrieta-Flores P (2014) Developing computational approaches for the study of movement: assessing the role of visibility and landscape markers in terrestrial navigation during Iberian late prehistory. In: Polla S, Verhagen P (eds) Computational approaches to movement in archaeology. Theory, practice and interpretation of factors and effects of long term landscape formation and transformation. De Gruyter, Berlin, pp 99-132

NASA Jet Propulsion Laboratory (2013) NASA Shuttle Radar Topography Mission Global 1 arc second. NASA EOSDIS Land Processes DAAC. https://earthexplorer.usgs.gov. Accessed 02/04/ 2016

National Museum of Korea (1979) Songguk-ri I. National Museum of Korea. In Korean

National Oceanic and Atmospheric Administration (1995) Visibility. National Weather Service. http://www.nws.noaa.gov/asos/vsby. $\mathrm{htm}$. Accessed on 11/12/2017

Oka R, Kusimba C (2008) The archaeology of trading systems, part 1: towards a new trade synthesis. J Archaeol Res 16(4):339-395

Park S-H (2015) Social boundaries and culture changes in the Bronze Age. Archaeology 14(1):5-42 In Korean with English abstract

Rhee S-N, Choi M-L (1992) Emergence of complex society in prehistoric Korea. J World Prehist 6(1):51-95

Sahlins M (2013) What kinship is-and is not. University of Chicago Press

Sakaguchi T, Morin J, Dickie R (2010) Defensibility of large prehistoric sites in the mid-Fraser region on the Canadian plateau. J Archaeol Sci 37:1171-1185

Service E (1975) Origins of the state and civilization: the process of cultural evolution. Norton, New York, NY

Smith C, Cochrane E (2011) How is visibility important for defense? A GIS analysis of sites in the Western Fijian Islands. Archaeol Ocean 46:76-84

Son J-H (2007) Reevaluation of the Songgukri site. Korea Antiquity 70: 35-62 In Korean with English abstract

Stein $\mathrm{G}$ (2010) Local identities and interaction spheres: modeling regional variation in the Ubaid horizon. In: Carter R, Philip G (eds) Beyond the Ubaid: transformation and integration in the late prehistoric societies of the Middle East 63. Oriental Institute of the University of Chicago, Chicago, pp 23-44

Stein G (2014) Economic dominance, conquest, or interaction among equals? Theoretical models for understanding culture contact in early near eastern complex societies. In: International congress of young archaeologists. University of Tehran Press, Tehran, pp 55-67 
Tilley C (1994) A phenomenology of landscape. Berg, Oxford

Trigger B (1967) Settlement archaeology — its goals and promise. Am Antiq 32(2):149-160

Tschan A, Raczkowski W, Latałowa M (2000) Perception and viewsheds: are they mutually inclusive? In: Lock G (ed) Beyond the map: archaeology and spatial technologies. IOS Press, Amsterdam, pp 28 48

Verhagen P (2018) Spatial analysis in archaeology: moving into new territories. In: Siart C, Forbriger M, Bubenzer O (eds) Digital Geoarchaeology. Springer, Cham, pp 11-25

Wang J, Robinson G, White K (2000) Generating viewsheds without using sightlines. Photogramm Eng Remote Sens 66:87-90

Wheatley D (1995) Cumulative viewshed analysis: a GIS-based method for investigating intervisibility, and its archaeological application. In: Lock G, Stancic Z (eds) Archaeology and Geographical Information Systems. A European Perspective. Taylor \& Francis Ltd, London, pp 171-186
Wheatley D, Gillings M (2000) Vision, perception and GIS: developing enriched approaches to the study of archaeological visibility. In: Lock G (ed) Beyond the map: archaeology and spatial technologies. IOS Press, Amsterdam, pp 1-27

Wiseman R (2016) Social distance in settled communities the conceptual metaphor, social distance is physical distance, in action. $\mathrm{J}$ Archaeol Method Theory 23:1023-1052

Wright D, MacEachern S, Lee J (2014) Analysis of feature intervisibility and cumulative visibility using GIS, Bayesian and spatial statistics: a study from the Mandara Mountains, Northern Cameroon. PloS one, 9(11), p.e112191

Yun H-P (2014) Hanguk cheongdonggisidae nonggyeongui gaesimic jeongae. Proceedings for 8th conference of Society for Korean Bronze Culture: 139-162. In Korean

Publisher's note Springer Nature remains neutral with regard to jurisdictional claims in published maps and institutional affiliations. 